\title{
The International Academy of Health Sciences Informatics: An Academy of Excellence
}

\author{
C. U. Lehmann, H.-A. Park, E. H. Shortliffe, P. Degoulet
}

\section{The Field of Health Sciences Informatics}

For the last 50 years, the International Medical Informatics Association (IMIA) has served as an important actor for the International community of biomedical and health informaticians. IMIA has been leading efforts to grow and nurture a collaborative global biomedical and health Informatics community that encourages and supports international initiatives to improve health for all. IMIA has brought researchers, scientists, educators, implementers, clinicians, and patients together from around the world to advance biomedical and health informatics science, education, and practice [1]. IMIA has achieved this goal through collaboration, development of guidelines and policies, learning, and exchange of knowledge, skills, and ideas.

The past decades have seen a tremendous growth and an increasing maturity in our field. Worldwide electronic health record implementation and health information exchange are on the rise requiring an ever growing, highly skilled, international labor force. Population health and the quantified health experience, as well as efforts in research informatics and translational / applied informatics have accelerated. As result, the maturing of the field has led to a growing group of international leaders and recognized experts in biomedical and health Informatics.

\section{International Academy of Health Sciences Informatics}

In 2015, the Board of Directors of the International Medical Informatics Association approved the creation of the International
Academy of Health Sciences Informatics (IAHSI). IAHSI will be a highly selected group of international leaders and experts in biomedical and health informatics.

\section{IAHSI Mission and Membership}

IAHSI will stimulate and direct research, play an important role in exchanging knowledge, educate the broader community, promote the field, advise governments and non-governmental organizations, mobilize governmental and non-profit support, produce policy documents (e.g., recommendations and position statements), and train the next generation of experts.

Similar to national Academies of Sciences, the International Academy IAHSI is intended to recognize excellent individual leaders, promote the exchange of methodologies, develop and foster new ideas, and encourage cross-border collaboration and sharing of resources. The Academy will also serve as an honor society that recognizes expertise in biomedical and health informatics internationally. Academy membership will be one of the highest honors in the international field of biomedical and health informatics. Election to membership carries the expectation of a candidate being recognized as a leader and promoter of the field. Elected members will hold the title of Member of the International Academy of Health Sciences Informatics for life.

\section{Election to the Inaugural Class of IAHSI}

The IMIA Board of Directors asked Drs. Edward H. Shortliffe and Patrice Degoulet, with the help of IMIA President Hyeoun-Ae Park, President-Elect Christoph U. Lehmann, and IMIA CEO Elaine Huesing, to shepherd the nomination of the initial candidates and the election of the inaugural class of IAHSI. The committee prepared a ballot of almost 200 names of leaders in the field. These nominees were proposed by IMIA's Honorary Fellows, board members, working group chairs, past officers, as well as past national leaders of IMIA member societies. All nominees were asked to select the founding members from the list of nominees. Because IMIA is an international body, the committee took steps to assure that the selected founding members represent all the regions of IMIA. Each nominee had up to 100 votes. The first 56 of any nominee's votes were mandatory and had to be allocated in accordance with a distribution that reflects the size of the member organizations within IMIA: Africa (2), Asia-Pacific (14), Europe (20), Latin America (6), Middle East (4), and North America (10). The remaining votes could then be distributed across the various regions. Nominees were asked to spread their "at-large" votes across the regions rather than focusing on only one or two. Because of regional ties in the votes, the final number of elected members reached 120 .

\section{The Future of IAHSI}

IMIA hopes to convene the inaugural class of IAHSI Members in August 2017 in Hangzhou, China, at the $16^{\text {th }}$ World Congress on Medical and Health Informatics (MEDINFO 2017). The new Academy will function as an elected body of members contained within IMIA and will elect a President, a treasurer, a secretary, and two members at large to serve as an executive committee. 
IAHSI will have its own rules and regulations that guide the organization, its activities, and its relationship with the parent organization. The founding members will create the rules and regulations and will establish both the processes for nominating and electing new members in future years as well as the activities that will define the Academy and its role in the biomedical and health informatics community.

\section{Inaugural Class of IAHSI Members}

Please join the IMIA Board of Directors, the special task force, and IMIA staff in congratulating the members of the inaugural class of the International Academy of Health Sciences Informatics (Table 1). You have achieved worldwide recognition and admiration by your peers and are truly the leaders and mentors of our field.

\section{Acknowledgement}

The authors would like to acknowledge IMIA CEO Elaine Huesing, whose extraordinary efforts made the election possible.

\section{References}

1. International Medical Informatics Association. Strategic Plan; 2017. Approved and in print.

http://dx.doi.org/10.15265/IY-2016-015

Table 1 Inaugural class of the International Academy of Health Sciences Informatics

\begin{tabular}{|c|c|c|c|c|c|}
\hline Abu-Hanna, Ameen & The Netherlands & Hersh, William & USA & Murray, Peter & UK \\
\hline Adlassnig, Klaus-Peter & Austria & Holmes, John H. & USA & Musen, Mark & USA \\
\hline Al Barrak. Ahmdd & Saudia Arabia & Hovenga, Evelyn & Australia & Nohr, Christian & Denmark \\
\hline Al-Shorbaji, Najeeb & Jordan & Hripcsak, George & USA & Ohno-Machado, Lucila & USA \\
\hline Altuwaiiri, Majid & Saudia Arabia & Hullin, Carol & Chile & Otero, Paula & Argentina \\
\hline Ammenwerth, Elske & Austria & Humphreys, Betsy L. & USA & Park, Hyeoun-Ae & South Korea \\
\hline Andersen, Stig Kjaer & Denmark & Hussein, Rada & Egypt & Patel, Vimla & USA \\
\hline Bakker, Ab & The Netherlands & Koch, Sabine & Sweden & Protti, Denis J. & Canada \\
\hline Ball, Marion & USA & Kohane, Isaac & USA & Rector, Alan & UK \\
\hline Bates, David W. & USA & Kouematchoua Tchuitcheu, Ghislain & Cameroon & Rienhoff, Otto & Germany \\
\hline Bellazzi, Riccardo & Italy & Kulikowski, Casimir & USA & Roberts, Jean & UK \\
\hline Blobel, Bernd & Germany & Kushniruk, Andre & Canada & Roger France, Francis & Belgium \\
\hline Chute, Christopher & USA & Liaw, Siaw-Teng & Australia & Séroussi, Brigitte & France \\
\hline Cimino, James & USA & Lindberg, Donald & USA & Shvo, Amnon & Israel \\
\hline Coiera, Enrico & Australia & Lorenzi, Nancy & USA & Shahar, Yuval & Israel \\
\hline De Moor, Georges & Belgium & Lovis, Christian & Switzerland & Shortliffe, Edward & USA \\
\hline Degoulet, Patrice & France & Lun, KC & Singapore & Sittig, Dean F. & USA \\
\hline Detmer, Don & USA & Luna, Daniel & Argentina & Stead, William W. & USA \\
\hline Engelbrecht, Rolf & Germany & Mandil, Salah Hussein & Sudan & Szolovits, Peter & USA \\
\hline Espinosa Lobato, J. Amado & Mexico & Mantas, John (loannis) & Greece & Takeda, Hiroshi & Japan \\
\hline Fieschi, Marius & France & Maojo, Victor & Spain & Talmon, Jan & The Netherlands \\
\hline Fox, John & UK & Marcelo, Alvin & Phillippines & Tanaka, Hiroshi & Japan \\
\hline Friedman, Charles P. & USA & Margolis, Alvaro & Uruguay & Tierney, William & USA \\
\hline Hannah, Kathryn & Canada & Moehr, Jochen & Canada & Wright, Graham & South Africa \\
\hline Hannan, Terry & Australia & Moen, Anne & Norway & Wu, Ying & China \\
\hline Hasman, Arie & The Netherlands & Moghaddam, Ramin & Iran & Wyatt, Jeremy & UK \\
\hline Haux, Reinhold & Germany & Moura Jr, Lincoln de Assis & Brazil & Zvarova, Jana & Czech Republic \\
\hline
\end{tabular}

